MICHAŁ BORODO

Uniwersytet Kazimierza Wielkiego w Bydgoszczy

michal.borodo@ukw.edu.pl

\title{
„WIDZIAŁ NA ULICY MURZYNA, ALE NIE LUDOŻERCĘ". O TŁUMACZENIU I POPRAWNOŚCI POLITYCZNEJ
}

\section{Abstract \\ "He Saw a Black Man in the Street, but Not a Cannibal". On Translation and Political Correctness}

The article focuses on Kaytek the Wizard, the English translation of Janusz Korczak's children's classic Kajtuś czarodziej, originally published in Poland in 1933. Translated by Antonia Lloyd-Jones, the book was published by Penlight Publications in New York in 2012, almost eighty years after the original publication. The article begins with an overview of the theoretical context of translating children's literatur with regard to issues such as censorship, political correctness and ideological manipulations. It demonstrates that contentious passages have often been mitigated in order to create a commercially or ideologically "proper" text, for example in the former countries of the Eastern Bloc, Spain or contemporary America. It then describes the context of the publication of the English version of Korczak's classic, shedding light on the roles of the copyright holder and translation commissioner, the publisher and the translator, also mentioning the English language reviews of the translation which appeared in literary journals. Following that, the article examines the translator's treatment of the original expressions and passages concerning racial issues and Black people, which would be considered racist today. These include references to Africans as "savages", "apes" or "cannibals", the reflection of the European racial stereotypes of that period. It is demonstrated that in her treatment of such lexical items the translator adopted a middle course, retaining some of the contentious passages but also partly omitting and toning down other controversial examples in question. The article also reflects on the role and constraints on the literary translator, who may be confronted with the ethical dilemma of either respecting the integrity of the original and recreating the collective consciousness of a bygone era or appropriating the 
original text through eliminating the passages negatively portraying Black people in the context of multicultural American society.

Key words: political correctness, children's literature translation, literary translation, Janusz Korczak

Słowa klucze: poprawność polityczna, przekład literatury dziecięcej, przekład literacki, Janusz Korczak

\section{Klasyka Korczaka 80 lat później}

Artykuł poświęcony jest powieści Janusza Korczaka pt. Kajtuś czarodziej z 1933 roku oraz jej angielskiemu przekładowi autorstwa Antonii Lloyd-Jones zatytułowanemu Kaytek the Wizard. Angielskie tłumaczenie, wydane prawie 80 lat po publikacji polskiego oryginału, ukazało się w 2012 roku nakładem nowojorskiego wydawnictwa Penlight Publications, m.in. dzięki dotacji Instytutu Książki, będącego w tym czasie właścicielem praw autorskich do wszystkich dzieł Korczaka.

Przekład ten stanowi wyjątkowo ciekawy materiał analityczny z kilku względów. Po pierwsze, nasuwa się pytanie, w jaki sposób został oddany przez tłumaczkę styl literacki Korczaka, niekiedy przesadnie lakoniczny i charakteryzujący się częstym użyciem elipsy. Po drugie, wart przeanalizowania jest sposób potraktowania w przekładzie szeregu elementów nacechowanych kulturowo, dotyczących polskiej obyczajowości, historii i folkloru. Po trzecie, intrygujący wydaje się sposób, w jaki zostały oddane w thumaczeniu charakterystyczne dla polskiego oryginału liczne fragmenty dotyczące kwestii rasowych, które według dzisiejszych standardów zostałyby bez wątpienia uznane za niepoprawne politycznie. To właśnie ten trzeci aspekt, dotyczący przedstawienia czarnoskórych bohaterów w thumaczeniu na język angielski, będzie przedmiotem rozważań w niniejszym tekście.

Celem artykułu jest zatem ustalenie, jaką strategię tłumaczeniową obrała Antonia Lloyd-Jones w przekładzie skierowanym do amerykańskiego czytelnika w dobie wszechobecnej poprawności politycznej. Czy, respektując integralność oryginału oraz z szacunku dla jego twórcy, w precyzyjny sposób odwzorowała sposób myślenia autora? Czy też zaproponowała nową interpretację, modernizując wspomniane fragmenty, co niekoniecznie byłoby bezzasadne w kontekście kultury docelowej, czyli wielokulturowego społeczeństwa amerykańskiego? W końcu, jaką rolę odegrały w przygotowywaniu 
tego przekładu instytucje patronujące temu przedsięwzięciu? Zanim przejdziemy do odpowiedzi na tak postawione pytania, warto w pierwszej kolejności pokrótce nakreślić kontekst teoretyczny związany z przekładem dla dzieci, a także wyjaśnić stosowane $\mathrm{w}$ tekście pojęcie poprawności politycznej.

\section{Przekład literatury dziecięcej a poprawność polityczna}

Na przełomie XX i XXI wieku badania nad przekładem literatury dziecięcej niejednokrotnie podejmowały temat wpływu uwarunkowań politycznych i ideologicznych na thumaczenie. Analizowano m.in. to, jak następujące po sobie przekłady klasyki literatury dziecięcej odzwierciedlały dominujące w danych okresach ideologie (np. Wunderlich 1992; Seago 1995; Dollerup 1999), omawiano kwestie cenzury i manipulacji (Craig 2001; Mdallel 2003; Thomson-Wohlgemuth 2003, 2006, 2009; Pokorn 2012) oraz zagadnienie poprawności politycznej i jej wpływu na ostateczny kształt tłumaczenia (Fernández López 2006; Thomson-Wohlgemuth 2004). Warto zauważyć, że tłumaczona literatura dziecięca stanowi pod tym względem wdzięczny materiał analityczny. Jej charakterystyczną cechą jest to, że bywa niekiedy, w szczególności w przypadku dawniejszych przekładów, poddawana różnego rodzaju modyfikacjom, mającym na celu złagodzenie lub wyeliminowanie treści uznanych za niewłaściwe dla młodego czytelnika. Byłoby uogólnieniem stwierdzenie, szczególnie współcześnie, że dotyczy to wszystkich tłumaczeń, jako że kwintesencją wielu tekstów literatury dziecięcej jest pewna przewrotność lub niestandardowe poczucie humoru, często doskonale w przekładzie oddane. Ingerencji dotyczących takich tematów, jak np. śmierć, przemoc, religia, seksualność, cielesność, kwestie rasowe, krytyka dorosłych itd., jest jednak w tłumaczonych książkach dla dzieci bardzo wiele (zob. np. Van Coillie 2011).

Przykłady można by mnożyć - doskonałą ilustracją takich ingerencji translatorskich jest np. częste cenzurowanie sposobu, w jaki Guliwer, po spożyciu dużej ilości wina, stara się ugasić pożar w pałacu Liliputów (O’Sullivan 2005: 87), znikająca ze świadectwa Lulejki w polskich wydaniach Pierścienia i Róży z lat 50. religia (Adamczyk-Garbowska 1988: 157) lub opisany przez Zohar Shavit (1986: 90) moment upadku Alicji na dnie króliczej nory, który w zależności od tłumacza zostaje na różne sposoby złagodzony. To samo dotyczy zresztą polskich tłumaczeń, nie wspominając o adaptacjach obrazkowych Disneya, gdzie moment upadku Alicji bywa 
w różnym stopniu ,zamortyzowany”. Ze względu na specyficznego adresata i niższy status kulturowy literatury dziecięcej tekst oryginału jest zatem w pewnych sytuacjach modyfikowany zgodnie z wyobrażeniami tłumacza bądź wydawcy na temat tego, co na tym etapie rozwoju jest odpowiednie, a co niewłaściwe. Można założyć, że literatura dziecięca będzie tym bardziej podatna na modyfikacje fragmentów niepoprawnych politycznie, a więc takie użycia języka, które mogą być potencjalnie obraźliwe, krzywdzące, deprecjonujące i/lub powielać uprzedzenia i stereotypy dotyczące przedstawicieli innych ras, mniejszości etnicznych lub grup społecznych.

Zabiegi polegające na modyfikowaniu lub eliminowaniu treści uznanych za „niewłaściwe” mają długą tradycję i występowały w różnych okresach historycznych m.in. w krajach o ustroju niedemokratycznym, gdzie w treść książek dla dzieci ingerowała cenzura. Na przykład po przeanalizowaniu dokumentów tworzonych przez cenzorów z byłej NRD Gabriele Thomson-Wohlgemuth zauważa, że takie tytuły jak Pippi Pończoszanka i Doktor Dolittle miały dość ,skomplikowaną historię wydawniczą" ze względu na „niewłaściwe przedstawienie osób czarnoskórych” (Thomson-Wohlgemuth 2004: 120). Z tego powodu po długich negocjacjach prowadzonych z Astrid Lindgren oraz z synem Hugh Loftinga ze wspomnianych powieści usunięto kilka rozdziałów (Thomson-Wohlgemuth 2004: 120). Lektura książki Roberta Looby'ego (2015) uświadamia, że tak radykalne zabiegi, jak usuwanie w całości rozdziałów o „niewłaściwej” wymowie, nie miało miejsca w przekładach literatury anglojęzycznej publikowanych w PRL-u. W odniesieniu do literatury skierowanej do dorosłego czytelnika Looby zauważa jednak wyraźną tendencję do łagodzenia lub pomijania uważanych za obraźliwe określeń rasowych, takich jak np. nigger, które było zazwyczaj konsekwentnie oddawane w thumaczeniu za pomocą słowa „Murzyn” (Looby 2015: 135-154). Co ciekawe, tę samą konwencję przekładową, polegającą na neutralizowaniu pejoratywnych odniesień rasowych, zauważa autor już w przekładach przedwojennych. W przypadku tłumaczeń anglojęzycznej literatury dziecięcej ingerencje ideologiczne polegające na pomijaniu lub łagodzeniu treści potencjalnie niewłaściwych i niepoprawnych nie występują na dużą skalę i są raczej powierzchowne, a bardziej znaczące wydają się, szczególnie w pewnych okresach, sama preselekcja i wycofywanie tekstów z obiegu (ibid. 158).

Współcześnie, o czym wspomina Emer O’Sullivan (2005: 86), zabiegi cenzorskie występują w literaturze dziecięcej np. w kontekście amerykańskim i dotyczą m.in. eliminowania z książek dla dzieci ilustracji 
zawierających elementy nagości. Inne przykłady ingerencji w kontekście amerykańskim podaje Thomson-Wohlgemuth (2004: 120-121), wskazując na tłumaczenia baśni Andersena, z których w wyniku korekty redakcyjnej usunięto fragmenty dotyczące m.in. przemocy, cielesności, religii, braku szacunku wobec dorosłych oraz, pod wpływem poprawno-politycznej wrażliwości na kwestie rasowe, określenia takie jak np. black magic przemianowano na bad magic. Rezultatem tego rodzaju „bowdleryzacji” jest tekst znacznie zubożony znaczeniowo i pozbawiony wcześniejszej wielowymiarowości, ale za to już jak najbardziej „odpowiedni” i „właściwy” w sensie komercyjnym i ideologicznym. Thomson-Wohlgemuth wskazuje na pewne analogie między wyżej wymienionymi praktykami stosowanymi w krajach bloku wschodniego a tymi występującymi w kontekście amerykańskim - w obydwu przypadkach dotyczą one cenzorowania treści uznanych odgórnie za niewskazane dla młodego czytelnika i niesłuszne ideologicznie w takich obszarach, jak religia, cielesność, przemoc, kolonializm czy kwestie rasowe.

Tym ostatnim zagadnieniem, a więc przekładem dla dzieci, kwestiami rasowymi i poprawnością polityczną, zajęła się m.in. Marisa Fernández-López (2006), która porównywała kolejne wydania hiszpańskich tłumaczeń dla dzieci z następującymi po sobie wydaniami ich angielskich pierwowzorów. Fernández zwracała uwagę na to, że podczas gdy oryginalne teksty angielskie były z czasem poddawane obróbce redakcyjnej, w wyniku czego stawały się bardziej poprawne politycznie, kolejne wydania tego samego hiszpańskiego przekładu pozostawały w tym zakresie niezmienione. Podczas gdy w następujących po sobie hiszpańskich wydaniach przekładu jednej z powieści Enid Blyton nadal pojawiają się fragmenty kreujące negatywny wizerunek Romów i Afrykanów, nie występują już one w przeredagowanych wydaniach oryginałów. W kolejnych angielskich wydaniach powieści The Story of Doctor Dolittle (pierwsze polskie thumaczenie: Doktor Dolittle i jego zwierzęta, przeł. Wanda Kragen) widoczne są ingerencje dotyczące warstwy leksykalnej (przykładowo takie określenia, jak white man, są zastępowane przez słowa man lub European, natomiast black man poprzez man lub African), jak również daleko idące ingerencje polegające na usunięciu akapitów i rozdziałów uznanych na niepoprawne politycznie (Fernández 2006: 50-51), natomiast w tekstach hiszpańskich zmiany te nie występują.

Podobne modyfikacje pojawiają się w powieści Roalda Dahla pt. Charlie and the Chocolate Factory (pierwsze polskie tłumaczenie: Karol i fabryka 
czekolady, przeł. Tomasz Wyżyński) i dotyczą odniesień do koloru skóry i miejsca pochodzenia pracujących w fabryce czekolady Willy'ego Wonki umpa lumpów. Odniesienia te zostały diametralnie zmienione w kolejnych angielskich wydaniach, ale już nie w wydaniach hiszpańskich ${ }^{1}$. I tak zdanie ze zmodyfikowanego, poprawnego politycznie angielskiego wydania „His skin was rosy-white, his long hair was golden-brown, and the top of his head came just above the height of Mr Wonka's knee" [jego skóra była różowo-biała, jego długie włosy były złocisto-brązowe, a czubkiem głowy sięgał tuż ponad kolano pana Wonki] posiada następujący odpowiednik w niezmienionej wersji hiszpańskiej: Su piel era casi negra, y la parte superior de su lanuda cabeza llegaba a la altura de la rodilla del señor Wonka [jego skóra była prawie czarna, a czubkiem wełnistej głowy sięgał tuż ponad kolano pana Wonki] (Fernández 2006: 51). Fernández upatruje przyczyny tych rozbieżności w odmiennej sytuacji społeczno-historycznej Hiszpanii. Twierdzi także, że wierność wobec pierwszego angielskiego wydania może być związana z prestiżem, jakim angielska literatura dziecięca cieszy się w tym kraju.

Poprawność polityczna, jak dowodzi Geoffrey Hughes (2010), to zjawisko złożone. $Z$ jednej strony, zakłada ona łagodzenie i tonowanie treści potencjalnie krzywdzących i obraźliwych, zwalczanie uprzedzeń i stereotypów za pomocą nowych lub neutralnie brzmiących sformułowań, czynienie zadość dziejowym niesprawiedliwościom i wyrównywanie szans dla środowisk marginalizowanych. $Z$ drugiej strony, jest postrzegana jako rodzaj inżynierii semantycznej, która, choć wynika ze szlachetnych pobudek, narzuca sztuczne i abstrakcyjne kody językowe, niekiedy utrudniające otwartą wymianę poglądów i przywodzące na myśl Orwellowską nowomowę. Wpływ poprawności politycznej na literaturę dziecięcą, jak wskazują wcześniej wspomniane przykłady, widoczny jest w działaniach wydawców, szczególnie amerykańskich, dbających o to, żeby książki dla młodego czytelnika wydawano według określonych poprawno-politycznych wytycznych (Hughes 2010: 248-249). Dotyczy to takich tytułów, jak np. Doktor Dolittle, Przygody Tintina, Przygody Hucka oraz książek Enid Blyton. Na przykład wydawana od 1929 roku seria Przygody Tintina, w dość stereotypowy sposób przedstawiająca

${ }^{1}$ Pojawia się w tym kontekście pytanie o polskie tłumaczenia powyższych tytułów literatury dziecięcej. Czy podlegają one modyfikacjom podobnie jak kolejne angielskie wydania pierwowzorów, czy też raczej podążają drogą nienaruszonych w sferze (nie)poprawności politycznej hiszpańskich tłumaczeń. Dopiero przeprowadzona w osobnym artykule dokładniejsza analiza dałaby odpowiedź na to pytanie. 
kultury nieeuropejskie, znalazła się w ogniu krytyki m.in. w roku 2007, kiedy zarówno w Belgii, jak i Wielkiej Brytanii wniesiono przeciwko niej skargi dotyczące uprzedzeń na tle rasowym względem rdzennych mieszkańców Konga (Hughes 2010: 248-249). Innym przykładem krytykowanego tytułu są Przygody Hucka z 1884 roku - w związku z występowaniem w tekście uznawanego dzisiaj za obraźliwe określenia nigger. Jak jednak zauważył cytowany przez Hughesa Lionel Trilling, jest to jedyne określenie, jakie mógł znać Huck - nieokrzesany i niewyedukowany chłopiec na amerykańskim Południu przed wojną secesyjną. Jest to fakt niekoniecznie chwalebny, ale jednak historyczny, z którym warto się skonfrontować, zamiast o nim zapominać lub pomijać milczeniem (Hughes 2010: 152).

\section{Kontekst wydawniczy}

Wydany w 1933 roku Kajtek czarodziej to historia obdarzonego bujną wyobraźnią, niespokojnego chłopca, który marzy o tym, aby pewnego dnia opanować sztukę czarodziejską. Kiedy to marzenie się spełnia, pomimo dobrych intencji, Kajtek nie zawsze potrafi zrobić właściwy użytek ze swoich magicznych zdolności. Nie będąc w stanie przewidzieć konsekwencji swoich poczynań, wprowadza chaos w Warszawie, o kilka godzin cofając wszystkie zegary, sprawia, że mieszkańcy stolicy zaczynają chodzić do tyłu, oraz wyczarowuje tajemniczą wyspę i pałac pośrodku Wisły. Po tych niezwykłych wydarzeniach Kajtek wyrusza za granicę w podróż obfitującą w fantastyczne przygody, w trakcie której zostaje bokserem w cyrku w Paryżu, aktorem w Hollywood, a nawet przemieniony w psa $\mathrm{z}$ trudem stara się odszukać drogę do domu. Kajtek czarodziej to zatem powieść o dorastaniu, opowieść o bohaterze dziecięcym, który w wyniku nabytych doświadczeń dojrzewa, zdobywając wiedzę na temat ludzkich ograniczeń, wolnej woli i odpowiedzialności za własne czyny.

Podczas gdy osoba autora powieści, wybitnego pedagoga, pediatry, działacza społecznego i pisarza, bohaterskiego „Starego Doktora”, nie wymaga przedstawienia, warto w kilku słowach przybliżyć postać Antonii Lloyd-Jones, znakomitej thumaczki literatury polskiej na język angielski, absolwentki Uniwersytetu w Oxfordzie, która ma w swoim dorobku przekładowym wiele tłumaczeń powieści, biografii i reportaży, m.in. takich autorów jak Zygmunt Miłoszewski, Paweł Huelle, Olga Tokarczuk czy Joanna Olczak-Ronikier. Lloyd-Jones dwukrotnie była laureatką nagrody 
Found in Translation, przyznawanej corocznie za najlepszy przekład literatury polskiej na język angielski. Po raz pierwszy otrzymała ją w 2008 roku za tłumaczenie Ostatniej Wieczerzy Pawła Huelle, a następnie w roku 2012 za aż siedem tłumaczeń wydanych w tym roku. Grzegorz Gauden, ówczesny dyrektor Instytutu Książki, tak skomentował to wyjątkowe osiągnięcie: „Ogromne wrażenie robi z jednej strony ich jakość, z drugiej - niezwykła wszechstronność tłumaczki. (...) W jednym tylko roku opublikowała zbiór literackich opowiadań i powieść, biografię, reportaż i klasyka literatury młodzieżowej” (Instytut Książki 2013). Klasyk literatury młodzieżowej to w tym wypadku oczywiście powieść Korczaka, Kajtuś czarodziej.

Przetłumaczona na język angielski jako Kaytek the Wizard powieść została wydana w momencie szczególnym - rok 2012 ustanowiono Rokiem Janusza Korczaka, obfitował on zatem w wiele wydarzeń i inicjatyw jemu poświęconych. Tłumaczenie zostało opublikowane przez amerykańskie wydawnictwo Penlight Publications w eleganckiej, twardej oprawie z czarno-białymi ilustracjami autorstwa Aviego Katza i dofinansowane w ramach Programu Translatorskiego CPOLAND, którego celem jest zwiększenie obecności polskiej literatury w przekładzie za granicą. Używając pojęć zaproponowanych przez Andre Lefevere'a (1992), można powiedzieć, że jako właściciel praw autorskich jednocześnie dofinansowujący to przedsięwzięcie, Instytut Książki był w tym przypadku instytucją sprawującą patronat nad przekładem, mającą potencjalnie niebagatelny wpływ na refrakcję tekstu oryginału.

Znamienny wydaje się w tym kontekście wybór pojawiającego się w angielskim tytule imienia głównego bohatera. Wśród rozważanych w trakcie przygotowywania przekładu imion znalazły się m.in. takie propozycje jak Willy the Wizard, a także Kazik i Casimir, za którymi opowiadał się wydawca, oraz imię Titus, zaproponowane przez tłumaczkę ze względu na to, że angielska wersja częściowo rymuje się z imieniem Kajtuś (Lloyd-Jones 2012). Natomiast Instytut Książki podkreślał, że tytuły książek Korczaka w miarę możliwości powinny pozostać niezmienione. Spośród kilku rozważanych możliwości tłumaczka ostatecznie wybrała wersję imienia raczej obco brzmiącą dla rodzimych użytkowników języka angielskiego, jaką jest Kaytek (Lloyd-Jones 2012).

W udzielonym w 2012 roku wywiadzie Antonia Lloyd-Jones wspomina również o tym, że chciała usunąć z angielskiej wersji powieści wyrażenia, które dziś zostałyby uznane za niepoprawne politycznie. W posłowiu do angielskiego przekładu tłumaczka odnosi się do nich w sposób następujący: 
Some phrases in the book sound extremely politically incorrect to the modern ear, but would not have been considered unusual when the book was written, such as pejorative references to black people as cannibals or apes, and to Jews as inferiors. Wishing to remain faithful to Korczak's original text, the publishers have chosen to leave these phrases as they were written (Lloyd-Jones 2012: 269)

Niektóre wyrażenia w książce brzmią współcześnie niezwykle niepoprawnie politycznie, ale nie zostałyby uznane za niezwykłe, gdy książka została napisana. Dotyczy to pejoratywnych odniesień do osób czarnoskórych jako kanibali lub małp oraz do Żydów jako osób o niższej pozycji społecznej. Chcąc zachować wierność wobec oryginalnego tekstu Korczaka, wydawcy zdecydowali się pozostawić te wyrażenia w formie, w jakiej zostały one zapisane (przeł. M.B.).

Fragment ten sugeruje, że tłumaczka odczuwała pewien dyskomfort, pozostawiając niektóre $\mathrm{z}$ potencjalnie kontrowersyjnych określeń $\mathrm{w}$ nienaruszonej formie. Jak widać, tłumacz jest głównym, ale oczywiście nie jedynym decydentem mającym wpływ na ostateczny kształt tłumaczenia.

Kwestię politycznie niepoprawnego charakteru powieści Korczaka podniesiono m.in. w recenzji, która ukazała się w nowojorskim magazynie „Kirkus Reviews”:

Tłumaczenie jest znakomite, a przypisy pomagają czytelnikowi zrozumieć miejscowe zwyczaje i geografię. Niestety na książce negatywnie odbija się charakterystyczny dla Europy połowy XX wieku rasizm, w szczególności w odniesieniu do Afryki i Afrykanów. Dla studentów zajmujących się literaturą dziecięcą książka i posłowie będą pouczające. W przypadku dzieci potrzebne będzie umiejscowienie w kontekście historycznym. Zawiera całostronicowe czarno-białe ilustracje. Fascynująca, ale ze skazą („Kirkus Reviews” 2012, przeł. MB).

Podobny komentarz pojawia się w recenzji na stronie Jewish Book Council, w której Sharon Elswit zauważa, że „w książce pozostało kilka niefortunnych odniesień odzwierciedlających język tamtych czasów, według którego Afrykanie to kanibale” („Left in are a few uncomfortable references

2 ,The translation is excellent, and notes are provided to help readers understand local customs and geography. Unfortunately, the book suffers from mid-20th-century European racism, particularly in its attitude toward Africa and Africans. Students of children's literature will find the book and the afterword illuminating. Children will need to place it in historical perspective. Illustrated with full-page black-and-white art. Fascinating but flawed". 
reflecting speech of that time where Africans are cannibals"), kończąc stwierdzeniem, że powieść ,posiada wartość historyczną, ale raczej nie jest polecana młodym czytelnikom współcześnie” (,novel of historic interest, rather than as one to recommend for young readers now" Elswit [bdw]). Warto zadać w tym kontekście pytanie, czy autorka przekładu przedwojennej powieści „ze skazą" faktycznie pozostawiła niepoprawne politycznie określenia w nienaruszonej formie, czy też zdecydowała się jednak na wprowadzenie pewnych modyfikacji w tłumaczeniu na język angielski.

\section{Dzicy, ludożercy i „czarne stworzenia”}

Występujące w Kajtusiu czarodzieju sformułowania, z których wiele uznano by współcześnie za niepoprawne politycznie, dotyczą przede wszystkim kwestii rasowych i wizerunku Afrykanina. Pierwsze tego rodzaju odniesienie pojawia się na początku rozdziału trzeciego:

Oryginal: Widział Kajtuś na ulicy takiego Murzyna, ale nie ludożercę (Korczak 1985: 29).

Tłumaczenie: Kaytek once saw a black man in the street, but he wasn't a cannibal (Korczak 2012: 37).

Określenia te mogą być uznane za odzwierciedlenie zbiorowej świadomości międzywojnia, kiedy to w rasowo homogenicznym społeczeństwie człowiek o czarnym kolorze skóry był kimś postrzeganym zapewne głównie przez pryzmat bohaterów literackich, takich jak opisany w Robinsonie Crusoe Piętaszek lub Kali z W pustyni $i$ w puszczy. Powieść Korczaka można zinterpretować szerzej, jako przykład europejskiej świadomości kolonialnej. Co prawda II Rzeczpospolita terytoriów zamorskich nie posiadała, miała jednak rozbudzone kolonialne aspiracje, widoczne chociażby w działalności Ligi Morskiej i Kolonialnej, do której w szczytowym okresie należało milion członków. Zainteresowanie tym tematem widoczne jest także w literaturze podróżniczej i młodzieżowej, która w latach 30. stanowiła stały element polskiego życia literackiego (Borkowska 2007: 23). Jak zauważa Marek Arpad Kowalski, ,[t]a popularna, acz o dużych wartościach artystycznych i warsztatowych literatura, tworzyła «kolonialną» atmosferę. Przeznaczona dla czytelników każdej właściwie kategorii wiekowej, młodych uwodziła fantazją egzotyki i przygody" (Kowalski 2005: 327). Echa fascynacji terytoriami zamorskimi i egzotyką zauważalne są też u Korczaka. 
W powieści Korczaka pojawiają się łącznie trzy odniesienia do ludożerców. Dwa pozostałe także zostały w przekładzie konsekwentnie zachowane.

Oryginal: Poczekajcie - odgraża się Kajtuś. - Niedługo kończy się miesiąc. Niech się dorwę do czarów, zaraz cała szkoła pofrunie do ludożerców" (Korczak 1985: 64).

Tłumaczenie: "Just you wait," thought Kaytek. "The month will soon be over. Just let me go into some magic spells and the whole school will fly off to the cannibals" (Korczak 2012: 81).

Oryginal: Dwa razy byłem rozszarpany: przez tygrysa i przez kulę armatnią. Topiłem się, trułem, wisiałem na szubienicy indyjskiej - w Afryce ludożercy ugotowali mnie w rosole z żółwi szylkretowych. Ale wszystko to głupstwo w porównaniu z dzisiejszą walką (Korczak 1985: 144).

Tłumaczenie: I've been torn to pieces twice - once by a tiger and once by a cannonball. I've drowned, been poisoned, and strung up on an Indian gallows - in Africa I was boiled by cannibals in a stock made of hawksbill turtles. But all that's nothing compared with today's fight (Korczak 2012: 176-177).

Warto zaznaczyć, że sformułowania te pojawiają się w powieści przygodowej dla dzieci i młodzieży. Choć są one bez wątpienia przykładem zniekształconego i stereotypowego wizerunku Afrykanina, z dzisiejszej perspektywy można je potraktować z przymrużeniem oka, zwracając uwagę na ich humorystyczny wydźwięk. Są one odzwierciedleniem myślenia o świecie w innej epoce i w innym kontekście kulturowym.

Podobne spostrzeżenia dotyczące charakterystycznej dla czasów minionych odmiennej wrażliwości można odnaleźć w artykule Piotra Blumczyńskiego i Joanny Najwer pt. Z amerykańskiej plantacji do międzywojennej Polski (czyli jak Uncle Remus został Murzynkiem Bam-Bo) (2011). W tekście omówiono wydane w 1929 roku polskie tłumaczenie opowiadań o Wujaszku Remusie (org. Uncle Remus) autorstwa Joela Chandlera Harrisa, którego twórczość ze szczegółami oddaje lokalny koloryt amerykańskiego Południa. Blumczyński i Najwer z jednej strony wskazują na znaczne odstępstwa thumaczki od tekstu oryginału, stwierdzając obrazowo, że „Wujaszek Remus swoją przeprowadzkę $\mathrm{z}$ amerykańskiej plantacji do międzywojennej Polski przypłacił utratą tożsamości, godności i roli, jaką odgrywał w oryginale” (Blumczyński, Najwer 2011: 169), a sam tekst „stanowi ciekawe świadectwo dawnych stereotypów kulturowych" (Blumczyński, Najwer 2011: 170). Z drugiej strony zaznaczają, że na „niekorzystne stereotypy rasowe (...) wyczuleni jesteśmy dziś w niewspółmiernie większym stopniu niż osiemdziesiąt lat temu, trudno więc 
winić tłumaczkę za inny poziom wrażliwości w tej sferze" (Blumczyński, Najwer 2011: 166). Trudno się nie zgodzić. Tekst Blumczyńskiego i Najwer przywodzi także na myśl podobne analizy autorstwa Judith Lavoie (2007) dotyczące pierwszego francuskiego przekładu Przygód Hucka, w którym Jim z doświadczonego i po ojcowsku zwracającego się do Hucka bohatera zostaje przemianowany na bohatera podległego i podrzędnego, na służącego pozbawionego godności przypisanej mu w oryginale.

Powieść Korczaka zawiera także wiele innych opisów, które wydają się nieco bardziej problematyczne niż wspomniane wcześniej odniesienia do ludożerców. Pojawiają się one przede wszystkim w rozdziale 13, w którym Kajtek podejmuje walkę z atletycznym, czarnoskórym bokserem w cyrku w Paryżu. Przeanalizujemy poniżej wybrane fragmenty opisujące to wydarzenie, zaczynając od momentu, w którym czarnoskóry bokser pojawia się na arenie:

Oryginal: Wychodzi Murzyn. Łyska białkami oczu. Pokazuje w uśmiechu białe zęby. Kłania się. Grzmot oklasków. Ktoś rzucił kwiaty, ktoś inny - pomarańcze. Murzyn zajada, oblizuje się, gładzi się po brzuchu (Korczak 1985: 138).

Tlumaczenie: At last - out comes the African. The whites of his eyes are shining. He smiles, flashing his white teeth. He bows. There's thunderous applause. Someone throws flowers, someone else throws tomatoes. The African eats them, licks his lips, rubs his stomach (Korczak 2012: 170).

Jest to jeden z kilku fragmentów, które w stereotypowy sposób przedstawiają wizerunek Afrykanina. Bezimienny czarnoskóry bokser ,łyska białkami oczu”, ,pokazuje w uśmiechu białe zęby” i ,gładzi się po brzuchu”, podczas gdy zgromadzona w cyrku publiczność rzuca mu pomarańcze (w przekładzie przemianowane na pomidory, co może dodatkowo sugerować nieprzychylny stosunek do występującego na arenie bohatera). W angielskim tłumaczeniu warto zwrócić uwagę na użycie niebudzącego negatywnych skojarzeń słowa African. Tłumaczka konsekwentnie stosuje określenie „Afrykanin” w miejsce mniej lub bardziej negatywnie nacechowanych znaczeniowo słów, takich jak „Murzyn”, „czarny” i ,dziki” występujących w oryginale.

Czarnoskóry bokser jest w pierwszej chwili rozbawiony i zaskoczony tym, że jego rywalem ma być ukrywający twarz za czerwoną maską chłopiec, co zostało opisane przez Korczaka w sposób następujący.

Oryginal: Murzyn też myśli, że to żart białych panów (Korczak 1985: 139).

Tłumaczenie: The African also thinks the white guys are having a joke (Korczak 2012: 171). 
Oryginal: Murzyn zakłopotany patrzy na Kajtusia. On jeden może poznał, bo dziki wierzy w czary.

- Czarny się boi. Patrzcie. Niech żyje Czerwona Maska! (Korczak 1985: 140)

Tłumaczenie: The confused African looks at Kaytek. He alone may have realized Kaytek's secret, because some Africans believe in magic.

"Look! The African's afraid. Long live the Red Mask!" (Korczak 2012: 171)

W obydwu powyższych fragmentach da się zauważyć pewne modyfikacje. Po pierwsze, negatywnie nacechowane zdanie ,dziki wierzy w czary” zostało przetłumaczone jako some Africans believe in magic. W ten sposób pejoratywne określenie „,dziki” zostało zastąpione określeniem „niektórzy Afrykanie", a jako całość przetłumaczone zdanie może zostać odebrane raczej jako odniesienie do odmiennych tradycji i obrzędów niż zabobonów i zacofania, co może sugerować zdanie oryginalne. Po drugie, określenie ,żart białych panów” zostało oddane w przekładzie jako the white guys are having a joke, choć potencjalnie można by je przełożyć np. jako the white masters are having a joke. Zamiast rezonującego historią kolonializmu i niewolnictwa określania „white masters”, tłumaczka zdecydowała się zatem na potoczne i bardziej neutralnie brzmiące określenie. Jednocześnie można zauważyć, że kolor skóry zostaje wygłuszony jedynie w przypadku Murzyna, a w przypadku ,białych panów” już nie, co jednak mimo wszystko implikuje tak wyraźnie zarysowaną u Korczaka odmienność Afrykanina i hierarchiczną relację między rasami. Teoretycznie byłoby możliwe całkowite wymazanie odniesień do koloru skóry w napisanej w 1933 roku powieści. Nie byłoby to zapewne jakimś nadzwyczajnym zabiegiem z punktu widzenia kultury docelowej w świetle przytoczonych wcześniej za Fernández i Thomson-Wohlgemuth przykładów. Z perspektywy kultury oryginału taki zabieg mógłby się jednak jawić jako posunięcie radykalne i nazbyt daleko idąca, nieuprawniona ingerencja ilustrująca karykaturalne oblicze, jakie przybiera niekiedy poprawność polityczna (Hughes 2010). Reasumując, w obydwu powyższych przykładach da się zauważyć interwencje tłumaczki łagodzące negatywny wydźwięk oryginału.

Dalsze fragmenty oryginału również w stereotypowy sposób przedstawiają afrykańskiego boksera, już nie tylko za pomocą takich określeń jak „czarny” lub „dziki”, których tłumaczka konsekwentnie unika, ale jeszcze bardziej pejoratywnych wyrażeń. Określenia te dochodzą z przyglądającej się zażartej walce rozemocjonowanej publiczności: 
Oryginal: Nie daj się, czarny! Zuch Czerwona Maska! Precz z małpą! Szympans, goryl! Murzyn już się nie śmieje (Korczak 1985: 140).

Tłumaczenie: Don’t give up, African! Well done, Red Mask! Down with the monkey! Chimp! Gorilla! The African isn't laughing any more (Korczak 2012: 172).

Na początku XXI wieku te słowa mogą swoją rasistowską wymową wywołać u czytelnika pewien dyskomfort, a nawet zażenowanie. Jest to zapewne jeden z momentów, w których czytelnik, być może osoba dorosła czytająca powieść Korczaka z dzieckiem na głos, przeciera oczy ze zdumienia, być może decyduje się na pauzę, być może nawet pomija zdanie w trakcie głośnego czytania. Jest to fragment, w którym interwencja w treść tekstu nie byłaby bezzasadna; być może taka ingerencja byłaby korzystna dla wizerunku autora oryginału, jak również względem samego czytelnika, który może być zdumiony określeniami i światopoglądem wyłaniającym się z Korczakowskiej powieści. Jak daleko jednak w swoich interwencjach może posunąć się tłumacz, na ile wolno mu tekst oryginału dostosowywać do własnych przekonań i własnego punktu widzenia i na ile jest on w stanie oryginał modyfikować, biorąc pod uwagę wytyczne wydawców, redaktorów i instytucji patronujących przekładowi?

Przyrównanie do zwierząt i wyeksponowanie animalistycznych cech czarnoskórego boksera jest zresztą widoczne także w innych fragmentach powieści:

Oryginal: Kołysząc się pochylony - Murzyn z krwią nabiegłymi oczami idzie na Kajtusia. (...) Olbrzymia czarna łapa mierzy w głowę Kajtusia. (...) Posypały się uderzenia drobnej ręki. Mięśnie Murzyna drgają pod skórą (Korczak 1985: 141). Tłumaczenie: Rocking and leaning forward with bloodshot eyes, the African is coming toward Kaytek. (...) The African aims an enormous black paw at Kaytek's head. (...) Kaytek's small hand showers punches on the African, whose muscles are twitching under the skin (Korczak 2012: 174).

Korczak stworzył w cytowanych fragmentach bardzo sugestywny obraz Afrykanina, który „,z krwią nabiegłymi oczyma” oraz „drgającymi pod skórą mięśniami” w kulminacyjnym momencie walki „czarną łapą mierzy” w chłopca. Brzmi to wręcz jak opis walki człowieka z pół człowiekiem, pół zwierzęciem, człekokształtnym, dzikim i nieokiełznanym przeciwnikiem wiedzionym zwierzęcym instynktem, gotowym w każdej chwili rzucić się do ataku. 
To, co następuje potem, kiedy walka jest już rozstrzygnięta, to jedna z najbardziej wymownych scen podkreślających hierarchiczność relacji rasowych pomiędzy białym chłopcem zwycięzcą a pokonanym Afrykaninem:

Oryginal: Murzyn zbliża się - stawia nogę Kajtusia na swym karku. Kajtuś otwiera oczy, z wysiłkiem wyciąga ręce. Murzyn opiera głowę na jego kolanach; Kajtuś całuje go w głowę, gładzi kędzierzawe kudły.

Ludzie płaczą. Huragan oklasków.

Olbrzym bierze Kajtusia na ręce ostrożnie - ostrożnie i wynosi z areny. (Korczak 1985: 142)

Thumaczenie: The African comes up and places Kaytek's foot on the back of his own neck. Kaytek opens his eyes, and stretches out his arms with an effort. The African rests his head on Kaytek's knees; Kaytek kisses him on the head, and strokes his curly hair.

People are crying. There's a hurricane of applause.

The giant gently picks Kaytek up and carries him out of the arena (Korczak 2012: 174-145).

Uznając swoją przegraną, pokonany przez chłopca czarnoskóry bohater w poddańczym geście skłania głowę, kładąc stopę chłopca na zgiętym karku, co niechybnie przywołuje na myśl kolonialne relacje pomiędzy „,białym panem" a czarnoskórym sługą lub niewolnikiem. Równocześnie jednak nie jest to scena jednoznaczna. Choć chłopiec w walce zwycięża, to jednak Afrykanin w opiekuńczym geście wynosi go z cyrkowej areny, omdlałego, doszczętnie wyczerpanego, będącego na łasce mocarnego czarnoskórego przeciwnika.

Jeden z najciekawszych - z perspektywy angielskiego thumaczenia opisów pojawia się pod koniec powieści w rozdziale 20 , we fragmencie przedstawiającym podróż podniebną niesionego na skrzydłach wiatru Kajtusia, obserwującego z góry kontynent afrykański:

Oryginal: Widzi palmy wysokie, dziwne zwierzęta i ptaki, człowieka czarnego. Ubogie namioty, lepianki, nędzne rupiecie naczyń i sprzętów; cudaczne ozdoby w uszach i w ustach. Trudno w czarnym stworzeniu dopatrzyć się brata; trudno wierzyć, że biały człowiek, jak uczy historia, równie dziki był dawno, kiedyś, przed laty (Korczak 1985: 218).

Tłumaczenie: He sees tall palm trees, strange animals and birds, and people with black skin. They live in poor tents or mud huts and have miserable bits of junk for utensils and equipment. They have weird decorations in their ears and lips. When you study history, it's incredible to think that white men lived just the same ways as them, a long, long time ago (Korczak 2012: 259). 
Szczególnie ostatnie zdanie oryginału zasługuje na uwagę. Rozpoczyna się ono od słów „Trudno w czarnym stworzeniu dopatrzyć się brata”, których jednak na próżno szukać w angielskim tłumaczeniu. Ze względu zapewne na swój negatywny wydźwięk i rasistowską wymowę Antonia Lloyd-Jones zdecydowała się na ich całkowite pominięcie. W kolejnym fragmencie również widoczna jest interwencja tłumaczki - fragment „trudno uwierzyć, że biały człowiek równie dziki był dawno, kiedyś, przed laty" został przemianowane na ,it's incredible to think that white men lived just the same ways as them a long time ago”, a więc „trudno uwierzyć, że biały człowiek żył w ten sam sposób jak oni przed laty”. W ten sposób kontrast pomiędzy „dzikim mieszkańcem Afryki” a „cywilizowanym białym człowiekiem” zostaje częściowo złagodzony w przekładzie. Ponownie pominięto też określenie „dziki”, które mogłoby przecież zostać potencjalnie przetłumaczone jako savage.

\section{W poszukiwaniu kompromisu}

Przeprowadzona w artykule analiza wskazuje, że choć w angielskim przekładzie powieści Korczaka występują ingerencje w warstwie leksykalnej, nie są one aż tak daleko idące jak te ujawnione w cytowanych na początku niniejszego tekstu analizach Fernández-López i Thomson-Wohlgemuth. Przytoczone w artykule anglojęzyczne recenzje przywołują jednak fragmenty dotyczące kwestii rasowych jako nie do końca kompatybilne z normami obowiązującymi w kulturze docelowej. Artykuł rzuca także nowe światło na uwarunkowania wydawnicze i rolę, jaką instytucje patronujące przekładowi mogą odgrywać w kontekście tłumaczenia literatury dziecięcej.

Pytanie, które nasuwa się po analizie występujących w Kajtusiu czarodzieju opisów dotyczących kwestii rasowych oraz ich angielskich tłumaczeń, brzmi: w jaki sposób należałoby potraktować tego rodzaju fragmenty w przekładzie na początku XXI wieku? Tłumacz może zapewne w takiej sytuacji rozważyć dwie diametralnie odmienne strategie translatorskie. Z jednej strony, respektując integralność oryginału, może potraktować tekst jako dokument czasów minionych, w precyzyjny sposób odwzorowując sposób myślenia autora i odzwierciedlając zbiorową europejską świadomość międzywojnia. Z drugiej strony, z uwagi na potencjalnego współczesnego czytelnika należącego do wielokulturowego społeczeństwa amerykańskiego, może zaproponować zupełnie nową interpretację, modyfikując i eliminując potencjalnie kontrowersyjne opisy w deprecjonujący sposób odnoszące się 
do innych ras lub mniejszości etnicznych. Obranie tej drugiej strategii byłoby podyktowane względami etycznymi, choć mogłoby też narazić tłumacza na zarzuty o częściowo nieuprawnione zawłaszczenie tekstu oryginału. Tłumaczka powieści Korczaka zdecydowała się na pewien kompromis, modyfikując i tonując niektóre z negatywnie nacechowanych odniesień rasowych, a inne fragmenty pozostawiając niezmienione, częściowo pod wpływem, jak sama przyznaje, patronów tego przekładu, którzy w udostępnianiu oryginału czytelnikom w nowym kontekście kulturowym odgrywają niekiedy równie istotną rolę co sam thumacz. Ocena tego kompromisu będzie z kolei zależeć od subiektywnej wrażliwości, wiedzy i przekonań indywidualnego czytelnika angielskiego przekładu.

\section{Bibliografia}

Adamczyk-Garbowska M. 1988. Polskie ttumaczenia angielskiej literatury dziecięcej: problemy krytyki przekładu, Wrocław: Zakład Narodowy im. Ossolińskich.

Blumczyński P., Najwer J. 2011. Z amerykańskiej plantacji do międzywojennej Polski (czyli jak Uncle Remus został Murzynkiem Bam-Bo), „Przekładaniec” 22/23, s. 159-171.

Borkowska G. 2007. Polskie doświadczenie kolonialne, „Teksty Drugie” 4, s. 15-24.

Craig I. 2001. Children's Classics under Franco. Oxford: Peter Lang.

Dollerup C. 1999. Tales and Translation, Amsterdam: John Benjamins.

Elswit S. [bdw]. Kaytek the Wizard, recenzja, http://www.jewishbookcouncil.org/book/ kaytek-the-wizard [dostęp: 20 września 2016].

Fernández-López M. 2006 [2000]. Translation Studies in Contemporary Children's Literature: A Comparison of Intercultural Ideological Factors, w: G. Lathey (red.), The Translation of Children's Literature: A Reader, Clevedon: Multilingual Matters, s. 41-53.

Hughes G. 2010. Political Correctness: A History of Semantics and Culture, Chichester: Wiley-Blackwell.

Instytut Książki. 2013. Found in Translation dla Antonii Lloyd-Jones, http://www.instytutksiazki.pl/wydarzenia,aktualnosci,29813,found-in-translation-dla-antonii-lloyd-jones.html [dostęp: 10 kwietnia 2016].

Kirkus Reviews. 22.07.2012. Kaytek the Wizard, recenzja, http://www.kirkusreviews. com/book-reviews/janusz-korczak/kaytek-wizard [dostęp: 20 września 2016].

Korczak J. 1985 [1933]. Kajtuś czarodziej, Warszawa: Nasza Księgarnia.

Korczak J. 2012. Kaytek the Wizard, przeł. A. Lloyd-Jones, New York: Penlight Publications. Kowalski M.A. 2005. Kolonie Rzeczpospolitej, Warszawa: Bellona.

Lavoie J. 2007. Mark Twain vs. William-Little Hughes: The Transformation of a Great American Novel, w: P. St-Pierre i P. C. Kar (red.), In Translation-Reflections, Refractions, Transformations, Amsterdam: John Benjamins, s. 95-106.

Lefevere A. 1992. Translation, Rewriting, and the Manipulation of Literary Fame, London-New York: Routledge. 
Lloyd-Jones A. 2012. Wywiad, http://culture.pl/pl/artykul/kajtus-kaytek-korczak-wywiad-z-tlumaczka-antonia-lloyd-jones [dostęp: 10 kwietnia 2016].

Looby R. 2015. Censorship, Translation and English Language Fiction in People's Poland, Leiden-Boston: Brill/Rodopi.

Mdallel S. 2003. Translating Children's Literature in the Arab World: The State of the Art, ,Meta” 48(1-2), s. 298-306.

O'Sullivan E. 2005. Comparative Children's Literature, London: Routledge.

Pokorn K.N. 2012. Post-Socialist Translation Practices: Ideological Struggle in Children's Literature, Amsterdam: John Benjamins.

Seago K. 2006 [1995]. Nursery Politics: Sleeping Beauty, or the Acculturation of a Tale, w: G. Lathey (red.), The Translation of Children's Literature: A Reader, Clevedon: Multilingual Matters, s. 175-189.

Shavit Z. 1986. Poetics of Children's Literature, London: The University of Georgia Press. Thomson-Wohlgemuth G. 2003. Children's Literature and Translation Under the East German Regime, „Meta” 48(1-2), s. 241-249.

- 2004. Children's Literature in Translation from East to West, w: S. Chapleau (red.), New Voices in Children's Literature Criticism, Lichfield: Pied Piper Publishing, s. 119-128.

2006. Flying High - Translation of Children's Literature in East Germany, w: J. Van Coillie, W.P.

Verschueren (red.), Children's Literature in Translation: Challenges and Strategies, Manchester: St. Jerome, s. 47-59.

2009. Translation under State Control: Books for Young People in the German Democratic Republic, New York-Abingdon: Routledge.

Van Coillie J. 2011. Nie ma śpiącej królewny bez kolców. Tłumaczenie baśni. Propozycja modelu analizy porównawczej, przeł. E. Wójcik-Leese, „Przekładaniec”22/23, s. 11-35.

Wunderlich R. 1992. The Tribulations of Pinocchio: How Social Change Can Wreck a Good Story, ,Poetics Today” 13(1), s. 197-219. 